\title{
Blood dynamics of mercury and selenium in northern elephant seals during the lactation period
}

\author{
Sarah Habran ${ }^{\mathrm{a}, *}$, Cathy Debier ${ }^{\mathrm{b}}$, Daniel E. Crocker ${ }^{\mathrm{c}}$, Dorian S. Houser ${ }^{\mathrm{d}}$, Krishna Das ${ }^{\mathrm{a}}$ \\ ${ }^{a}$ Laboratory for Oceanology - MARE Center B6c, University of Liege, 4000 Liege, Belgium \\ ${ }^{\mathrm{b}}$ Unité de Biochimie de la Nutrition, Institut des Sciences de la vie, Université catholique de Louvain, Place Croix du Sud 2/8, 1348 Louvain-la-Neuve, Belgium \\ ' Department of Biology, Sonoma State University, Rohnert Park, CA 94928, USA \\ d BIOMIMETICA, Santee, CA 92071, USA
}

\section{A R T I C L E I N F O}

\section{Article history:}

Received 8 November 2010

Received in revised form

1 June 2011

Accepted 15 June 2011

\section{Keywords:}

Mirounga angustirostris

Mercury

Selenium

Lactation

\begin{abstract}
A B S T R A C T
The effects of reproduction and maternal investment (i.e., milk transfer) on trace element levels remain poorly understood in marine mammals. We examined the blood dynamics of mercury (Hg) and selenium (Se) during lactation in the northern elephant seal (Mirounga angustirostris), a top predator from the North Pacific Ocean. Total Hg and Se levels were measured in whole blood and milk of 10 mother-pup pairs on days 5 and 22 of lactation. Both $\mathrm{Hg}$ and Se were transferred to offspring through the milk. Results suggested that the maternal transfer of Se was prominent during lactation, whereas the Hg transfer was larger during gestation. The lactation period affected $\mathrm{Hg}$ and Se levels in the blood of elephant seal mothers and pups. Physiological processes and their relationship to body condition should be considered carefully when interpreting trace element levels in the framework of biomonitoring.
\end{abstract}

(C) 2011 Elsevier Ltd. All rights reserved.

\section{Introduction}

Marine mammals have been used as sentinel species of pollution in the marine environment (Bossart, 2006). As long-lived top predators in the trophic network, marine mammals accumulate high levels of chemicals such as organochlorines (Debier et al., 2006, 2003) and trace elements (Das et al., 2003). Several exposure pathways for the uptake of trace elements in marine mammals may occur (Table 1 ), but many studies suggest that diet constitutes the main pathway of exposure (Das et al., 2003; Dehn et al., 2006). In addition, pollutant concentrations in marine mammals vary as a function of age, body condition, and diet selection, among other things (Caurant et al., 1994; Das et al., 2003) (Table 1).

Mercury $(\mathrm{Hg})$ contamination has received much attention in human and animal studies. It enters the aquatic food web, where it both biomagnifies and bioaccumulates. Both organic and inorganic forms of $\mathrm{Hg}$ are toxic because of their high affinity for thiolcontaining enzymes and proteins. However, they exhibit distinct toxicity because of different patterns of uptake and organ distribution (Gallagher and Lee, 1980). The most neurotoxic form of $\mathrm{Hg}$ that

\footnotetext{
* Corresponding author.

E-mail addresses: S.Habran@ulg.ac.be (S. Habran), cathy.debier@uclouvain.be (C. Debier), crocker@sonoma.edu (D.E. Crocker), biomimetica@cox.net (D.S. Houser) Krishna.Das@ulg.ac.be (K. Das).
}

can be found in animals is the organic form, methylmercury - MeHg (Khan and Wang, 2009). Consuming fish elevated in MeHg causes adverse health effects ranging from neurodevelopmental deficits in offspring to increased risk of myocardial infarction in adults (Khan and Wang, 2009; National Research Council, 2000; Sunderland et al., 2009).

Unlike $\mathrm{Hg}$, which has no known function in mammals, Se is an essential element. It functions through selenoproteins such as glutathione peroxidase (Dorea, 2002), and protects animals from the toxicity of both inorganic $\mathrm{Hg}$ and $\mathrm{MeHg}$ (Khan and Wang, 2009). In higher-trophic marine animals, demethylation processes of $\mathrm{MeHg}$ are known to occur in the liver with a subsequent formation of $\mathrm{HgSe}$ granules (tiemannite), explaining the 1:1 M ratio of Se and $\mathrm{Hg}$ observed in these animals (Cuvin-Aralar and Furness, 1991; Koeman et al., 1973; Nigro and Leonzio, 1996). The biomineral $\mathrm{HgSe}$ is assumed to be an inert end-product of the detoxification pathway (Martoja and Berry, 1980). The formation of an equimolar $(\mathrm{HgSe})_{\mathrm{n}}$ polymer that is bound to the plasma selenoprotein $\mathrm{P}$ (Sel P) was found in the bloodstream and identified (Yoneda and Suzuki, 1997). This (HgSe)-Sel $P$ is thought to also be a precursor of the crystalline HgSe (Ikemoto et al., 2004). Selenium is beneficial at lower concentrations, but it becomes toxic at higher concentrations (Dumont et al., 2006; Janz et al., 2010; Kim and Mahan, 2001), and the range between deficiency, essentiality, and toxicity is very narrow. Marine mammals do not appear to be as sensitive to dietary organic Se exposure as fish or birds, but no data concerning the 
Table 1

Routes of entry and factors affecting levels of trace elements in marine mammals.

\begin{tabular}{ll}
\hline Routes of entry & Factors \\
\hline Food (ingestion) & Age \\
Sea water (ingestion) & Trophic level/diet \\
Placenta (maternal transfer) & Sex \\
Milk (maternal transfer) & Metabolic rate \\
Lungs (atmosphere) & Tissue \\
Skin (absorption) & Geographic location \\
& (anthropogenic/natural sources) \\
& Physiological status \\
& - Body condition - nutritional status \\
& (fasting) \\
& - Reproductive status (gestation, lactation) \\
& - Molting (pinnipeds) \\
\end{tabular}

ratio between essentiality and toxicity exist for wild aquatic mammalian species (Janz et al., 2010).

Evaluation of current contaminant effects on a wild marine mammal population requires samples collected from living animals (Bryan et al., 2007; Griesel et al., 2008). Accessible samples from free-ranging marine mammals are generally limited to blood, fur/hair, skin biopsies, saliva, and feces (Andrade et al., 2007; Fossi and Marsili, 1997; Griesel et al., 2008; Stavros et al., 2008a). Blood from free-ranging marine mammals has become increasingly used in determining baseline levels of trace elements (Brookens et al., 2007; Bryan et al., 2007; Das et al., 2008; Gray et al., 2008; Griesel et al., 2008; Kakuschke et al., 2005; Nielsen et al., 2000; Stavros et al., 2008a; Woshner et al., 2008). Their concentrations found in blood may be useful in comparing contaminant exposure to humans and other mammals. Although contaminant concentrations in blood and skin relate to the total body burden (Bryan et al., 2007; Monaci et al., 1998), blood may also reflect the current exposure or remobilization. Little is known about the effects of the nutritional and physiological status (e.g., fasting, gestation, lactation or molting) on trace element levels in marine mammals. Further, the dynamics of tissue-specific trace elements modulated by these processes are yet to be determined. These processes need to be considered when trace element concentrations in blood are compared between individuals and over different sampling periods (Gray et al., 2008). Knowledge about the maternal transfer of metals to offspring is also very limited in marine mammals. Previous studies showed that females may pass some trace elements to their offspring through the placenta (Lahaye et al., 2007; Storelli and Marcotrigiano, 2000; Wagemann et al., 1988; Yang et al., 2004, 2008). Nevertheless, the importance of how these modes of transfer occur to element dynamics remains to be seen (Woshner et al., 2008). Trace element levels in the milk of marine mammals have only been reported once in harp seals, Pagophilus groenlandicus (Wagemann et al., 1988), and in some single cases of other species (Caon et al., 2008; Frodello et al., 2002; Rosas and Lehti, 1996).

In the present study, the blood dynamics of $\mathrm{Hg}$ and Se during lactation were investigated in the northern elephant seal (NES,
Mirounga angustirostris), a top marine predator from the North Pacific Ocean. As in other pinnipeds, the NES come ashore to give birth and suckle their young. In addition, they mate and molt on land. During the breeding season, females give birth shortly after arrival at the rookery and nurse a single pup for an average of 24-28 days. They will then abruptly wean their pup and return to sea to forage (Le Boeuf and Laws, 1994). They fast throughout the nursing period while secreting a fat-rich milk synthesized from their body reserves (Le Boeuf and Laws, 1994). Lactating females may lose more than a third of their initial body mass during lactation, up to $60 \%$ of their body fat and $25 \%$ of their body protein (Crocker et al., 2001). Meanwhile, the pups gain around $90 \mathrm{~kg}$ during the suckling period (Crocker et al., 2001). This intense and short period is thus characterized by an important mass transfer between the mother and the pup, without further external uptake of $\mathrm{Hg}$ and $\mathrm{Se}$ (from food or water). This life history feature of the NES makes it an excellent 'model' in which to study the effects of reproduction and maternal investment (i.e., milk transfer) on the levels of trace elements in marine mammals. This work presents a first longitudinal study on ten mother-pup pairs of northern elephant seals. Objectives of the current study were to: 1) quantify and describe the dynamics of total $\mathrm{Hg}(\mathrm{THg})$ and Se in blood and milk during lactation; and 2) study the maternal transfer of $\mathrm{THg}$ and Se to offspring via nursing. The dietary indicators, such as carbon and nitrogen stable isotopes, have been analyzed in these same NES samples in a previous study (Habran et al., 2010). These dietary indicators were related to maternal $\mathrm{THg}$ and Se levels.

\section{Materials and methods}

\subsection{Field techniques}

This study was conducted at Año Nuevo State Reserve, California, USA $\left(37^{\circ} 06^{\prime} 30^{\prime \prime} \mathrm{N}, 122^{\circ} 20^{\prime} 10^{\prime \prime} \mathrm{W}\right)$, during the 2005 breeding season (January-February). Ten mother-pup pairs were captured on day 5 of lactation (early lactation) and recaptured on day 22 of lactation (late lactation). Whole blood samples were collected at each capture from the extradural vein in Vacutainer ${ }^{\mathrm{TM}}$ red top serum tubes. Milk was expressed from the teat using a clean cut-off syringe and was transferred to $15 \mathrm{ml}$ plastic tubes. Animal-handling and sample-collection methods are described in Habran et al. (2010). At each capture, the length and mass of both mother and pup were, respectively, measured using a standard measuring tape, and weighed using a scale (capacity $1000 \pm 1 \mathrm{~kg}$ and $500 \pm 0.2 \mathrm{~kg}$ ) suspended from a tripod. The pup's sex was determined. Biometric data on the mother-pup pairs are summarized in Table 2. Whole blood and milk samples were kept on ice in the field (at $4{ }^{\circ} \mathrm{C}$ ) and then stored at $-20^{\circ} \mathrm{C}$ in the laboratory until analysis.

\section{2. $\mathrm{Hg}$ and Se analyses}

The samples of whole blood and milk were thawed and homogenized. Aliquots of $1 \mathrm{ml}$ blood and milk were accurately weighted to the nearest $0.1 \mathrm{mg}$ and were subjected to microwave-assisted digestion in Teflon ${ }^{\mathrm{TM}}$ vessels with $4 \mathrm{ml} \mathrm{HNO}_{3}(65 \%)$, $1 \mathrm{ml} \mathrm{H}_{2} \mathrm{O}_{2}(30 \%)$ and $2 \mathrm{ml}$ of $18.2 \mathrm{M} \Omega-\mathrm{cm}$ deionized water. After cooling, samples were diluted to $50 \mathrm{ml}$ with $18.2 \mathrm{M} \Omega$-cm deionized water in a volumetric flask. Total $\mathrm{Hg}$ (THg) levels were measured by atomic absorption spectroscopy (DMA-80, Direct Mercury Analyzer, Milestone). The method has been validated for digested matrices using US EPA Method 7473. Quality assurance methods included evaluation by measuring blanks, duplicates, and certified reference materials (CRMs) - DORM-2 and DOLT-3 (National Research Council, Canada) with every 10 samples. Recovery of $\mathrm{THg}$ in CRMs ranged from $92 \%$ to $106 \%$, averaging $98 \pm 3 \%$. Se levels were determined by inductively coupled plasma mass spectroscopy (ICP-MS, PerkinElmer,

Table 2

Biometry of northern elephant seal mothers and pups on days 5 and 22 of lactation; mean \pm SD (range).

\begin{tabular}{|c|c|c|c|c|c|}
\hline & & $n$ & Mass (kg) & Standard length $(\mathrm{cm})$ & Axial girth $(\mathrm{cm})$ \\
\hline Mothers & $\begin{array}{l}\text { Day } 5 \\
\text { Day } 22\end{array}$ & $\begin{array}{l}10 \\
10\end{array}$ & $\begin{array}{l}453 \pm 55(401-588) \\
330 \pm 49(283-448)\end{array}$ & $\begin{array}{l}256 \pm 14(240-284) \\
257 \pm 12(232-278)\end{array}$ & \\
\hline Pups & $\begin{array}{l}\text { Day } 5 \\
\text { Day } 22\end{array}$ & $\begin{array}{r}9 \\
10\end{array}$ & $\begin{array}{c}43 \pm 3(37-48) \\
114 \pm 8(97-122)\end{array}$ & $\begin{array}{l}127 \pm 5(117-133) \\
146 \pm 8(129-152)\end{array}$ & $\begin{aligned} 87 & \pm 7(75-99) \\
128 & \pm 5(119-136)\end{aligned}$ \\
\hline
\end{tabular}

Lactation duration (day): $25 \pm 2$ (22-29).

Pup sex ratio: 40:60 (female:male). 

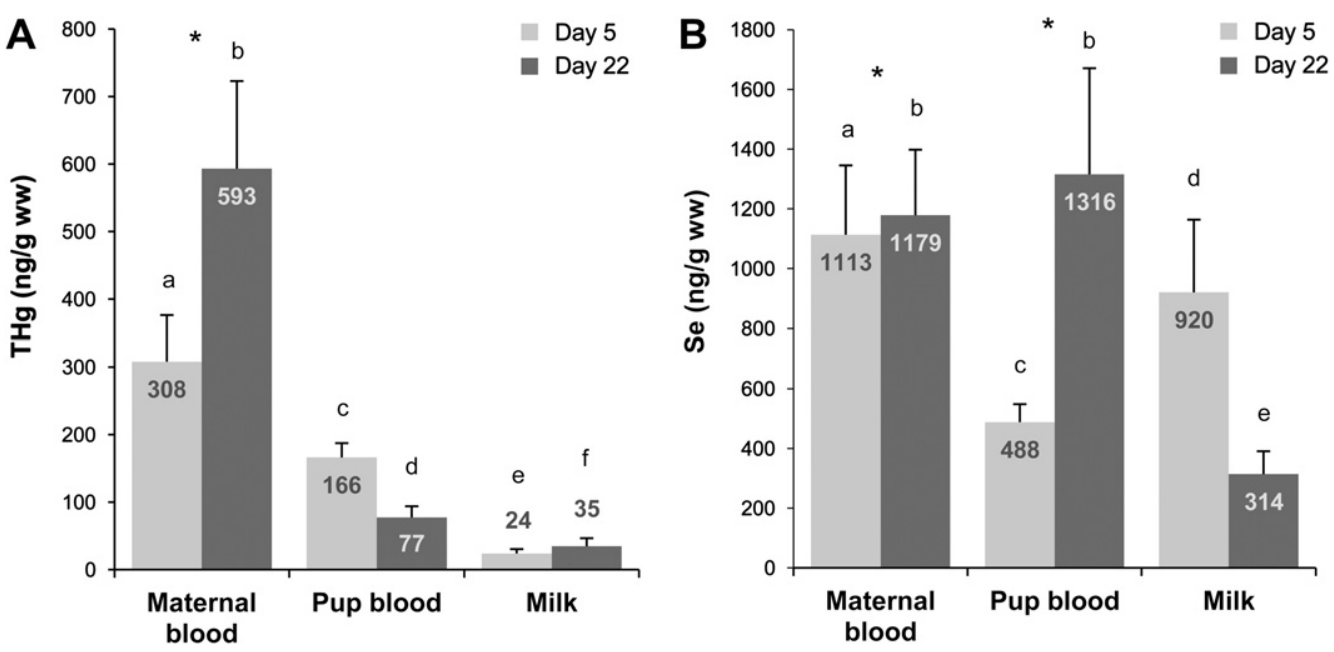

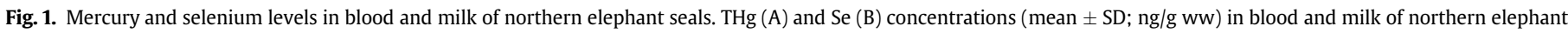

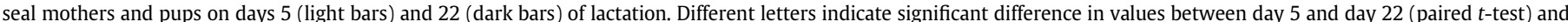

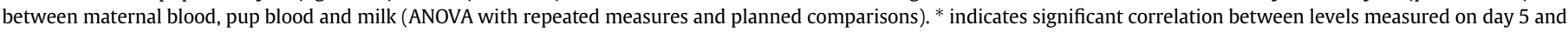
day 22 (Bravais-Pearson correlation).

Sciex, DCR 2). An internal standard $\left({ }^{103} \mathrm{Rh}\right.$, CertiPUR ${ }^{\circledR}$, Merck) was added to each sample and calibration standard solutions. Quality control and quality assurance for ICP-MS included field blanks, method blanks, and CRMs - DORM-2 and DOLT-3. Recovery of Se in CRMs ranged from $85 \%$ to $100 \%$, averaging $90 \pm 5 \%$. The method detection limits (MDL) for THg and Se were $1 \mathrm{ppb}$ and $0.166 \mathrm{ppb}$, respectively. All samples were above the MDL. Reported concentrations for both elements are expressed on a wet weight basis in ng/g. Note that throughout the text, 'blood' refers to whole blood.

\subsection{Statistical analyses}

A Kolmogorov-Smirnov test was used to determine whether data departed from normality. The variables were normally distributed and parametric tests were used for statistical analyses. To evaluate changes in $\mathrm{THg}$ or Se levels during lactation in blood and milk, paired $t$-tests were used to compare means in early (day 5) and late (day 22) lactation. Analysis of variance (ANOVA) with repeated measures was used to determine equality of the THg or Se levels among the different tissues sampled. A test was carried out for each sampling (on days 5 and 22) and means were compared pairwise using planned comparisons. The Bravais-Pearson correlation coefficient was used to test correlations between the two variables. Statistical analysis of the data was performed using Statistica software (Statsoft Inc., version 7.1) with $\alpha=0.05$. Results are presented as means \pm standard deviation (S.D.).

\section{Results}

\subsection{Comparison between early and late lactation}

The mean THg and Se concentrations in blood and milk for early (day 5) and late (day 22) lactation are presented in Fig. 1. All THg and Se concentrations in blood and milk differed significantly between day 5 and day 22 of lactation. In comparison with levels on day 5, maternal blood had higher THg levels on day 22 (308 vs. $593 \mathrm{ng} / \mathrm{g}$ ww, paired $t$-test; $P<0.001, n=10$ ), while pup blood had lower THg levels on day 22 (166 vs. $77 \mathrm{ng} / \mathrm{g}$ ww, paired $t$-test; $P<0.001, n=9)$. Milk had higher THg levels in late lactation (24 vs. $35 \mathrm{ng} / \mathrm{g}$ ww, paired $t$-test; $P=0.036, n=10)$. For Se, maternal and pup blood had higher levels on day 22 (1113 vs. 1179 and 488 vs. $1316 \mathrm{ng} / \mathrm{g} \mathrm{ww}$, paired $t$-test; $P<0.001, n=10$ and 9 , respectively). Milk had lower Se levels in late lactation (920 vs. $314 \mathrm{ng} / \mathrm{g}$ ww, paired $t$-test; $P<0.001, n=10$ ). Correlations of values between day 5 and day 22 were significant only for THg and Se in maternal blood and for Se in pup blood $(r=0.94,0.99$, and 0.85 respectively, for all $P<0.05$ )

\subsection{Comparison and relationships between mother and offspring}

THg levels were higher in maternal blood than in pup blood in early and late lactation (122-516 ng/g ww higher). Se levels were higher in maternal blood than in pup blood only in early lactation (632 ng/g ww higher). Both THg and Se levels differed significantly between blood and milk. Detailed results are given in Table 3. Significant positive relationships between maternal and pup blood were observed only on day 22 for THg levels and on days 5 and 22 for Se levels (Table 3).

Table 3

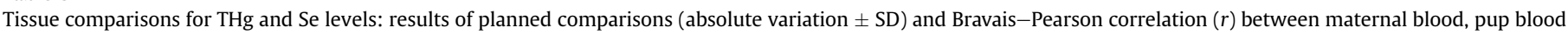
and milk on day 5 and on day 22 of lactation.

\begin{tabular}{|c|c|c|c|c|c|c|c|c|}
\hline & \multicolumn{2}{|c|}{ vs. } & \multicolumn{3}{|c|}{ Day 5} & \multicolumn{3}{|c|}{ Day 22} \\
\hline & & & $n$ & $|\Delta| \pm \mathrm{SD}$ & $r$ & $n$ & $|\Delta| \pm \mathrm{SD}$ & $r$ \\
\hline \multirow[t]{3}{*}{$\mathrm{THg}$} & Maternal blood & Pup blood & 9 & $\begin{array}{l}122 \pm 37 \\
P<0.001\end{array}$ & $\begin{array}{l}-0.23 \\
P=0.547\end{array}$ & 10 & $\begin{array}{l}516 \pm 116 \\
P<0.001\end{array}$ & $\begin{array}{l}0.85 \\
P=0.002\end{array}$ \\
\hline & Maternal blood & Milk & 10 & $\begin{array}{l}284 \pm 70 \\
P<0.001\end{array}$ & $\begin{array}{l}-0.20 \\
P=0.576\end{array}$ & 10 & $\begin{array}{l}559 \pm 123 \\
P<0.001\end{array}$ & $\begin{array}{l}0.61 \\
P=0.059\end{array}$ \\
\hline & Pup blood & Milk & 9 & $\begin{array}{l}142 \pm 21 \\
P<0.001\end{array}$ & $\begin{array}{l}0.17 \\
P=0.654\end{array}$ & 10 & $\begin{array}{l}43 \pm 10 \\
P<0.001\end{array}$ & $\begin{array}{l}0.79 \\
P=0.007\end{array}$ \\
\hline \multirow[t]{3}{*}{ Se } & Maternal blood & Pup blood & 9 & $\begin{array}{l}632 \pm 192 \\
P<0.001\end{array}$ & $\begin{array}{l}0.91 \\
P=0.001\end{array}$ & 10 & $\begin{array}{l}137 \pm 235 \\
P=0.097\end{array}$ & $\begin{array}{l}0.77 \\
P=0.010\end{array}$ \\
\hline & Maternal blood & Milk & 10 & $\begin{array}{l}193 \pm 217 \\
P=0.020\end{array}$ & $\begin{array}{l}0.58 \\
P=0.076\end{array}$ & 10 & $\begin{array}{l}865 \pm 168 \\
P<0.001\end{array}$ & $\begin{array}{l}0.76 \\
P=0.010\end{array}$ \\
\hline & Pup blood & Milk & 9 & $\begin{array}{l}429 \pm 221 \\
P<0.001\end{array}$ & $\begin{array}{l}0.68 \\
P=0.042\end{array}$ & 10 & $\begin{array}{l}1002 \pm 322 \\
P<0.001\end{array}$ & $\begin{array}{l}0.52 \\
P=0.124\end{array}$ \\
\hline
\end{tabular}




\section{3. $\mathrm{Hg}-$ Se interaction}

No significant relationship was observed between $\mathrm{THg}$ and $\mathrm{Se}$ levels in blood or milk. However in maternal blood, the increase rate of Se between day 5 and day 22 of lactation (Se $\Delta_{\text {relative }}$ ) was significantly correlated with the increase rate of THg during lactation (THg $\left.\Delta_{\text {relative }}\right)(r=0.80, P=0.005$; Fig. 2$)$. The molar ratio of Se and $\mathrm{THg}$ in maternal blood was quite steady during lactation (3-12), but it highly varied in pup blood (5-74) and milk (13-167) (Fig. 3).

\subsection{Influence of biometry and diet}

We tested relationships between the dietary indicators determined in Habran et al. (2010) (i.e., $\delta^{13} \mathrm{C}, \delta^{15} \mathrm{~N}$, and C:N ratios) and $\mathrm{THg}$ and Se levels. Only Se levels and $\delta^{13} \mathrm{C}$ values in maternal blood showed a strong, significant negative relationship $(r=-0.96$, $P<0.001$ on day 5 , Fig. $4 ; r=-0.88, P=0.001$ on day 22). In parallel, Se levels and body mass were negatively correlated ( $r=-0.82, P=0.003$ on day 5 , Fig. $4 ; r=-0.81, P=0.004$ on day $22)$, and $\delta^{13} \mathrm{C}$ values and body mass in mothers showed a positive relationship $(r=0.88, P=0.001$ on day $5 ; r=0.69, P=0.026$ on day 22 ). No other relationships were observed between biometric parameters (mass, length, lactation duration) and either $\mathrm{THg}$ or Se levels in maternal blood, pup blood, and milk (results not shown).

\section{Discussion}

Northern elephant seal females produce energy-rich milk and its composition changes over lactation. The milk fat content rises during lactation from approximately $15 \%$ to $55 \%$, while the water content falls from $75 \%$ to a level of 35\% (Riedman and Ortiz, 1979). Milk protein content remains fairly constant during lactation (around 12\%, Crocker et al., 2001). Detectable levels of THg were measured into the NES milk, and they rose from 24 to $35 \mathrm{ng} / \mathrm{g} \mathrm{ww}$ between early and late lactation. Although the increasing $\mathrm{Hg}$ values in maternal blood might explain a higher $\mathrm{Hg}$ intake into the milk in late lactation, no relationship was found between maternal blood and milk (Table 3). Besides, milk values estimated in dry weight basis showed a weaker increase in late lactation ( 48 and $52 \mathrm{ng} / \mathrm{g} \mathrm{dw}$

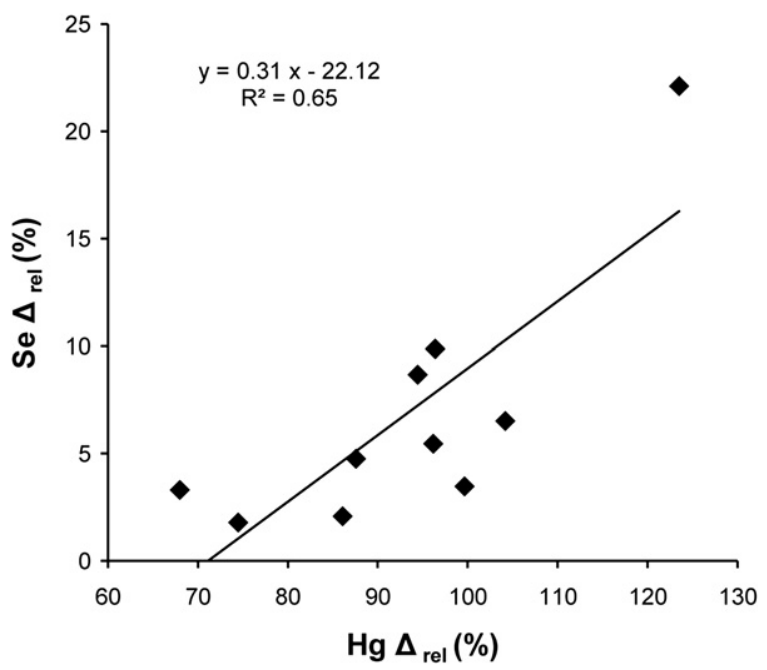

Fig. 2. Relationship between Se and THg in maternal blood measured during lactation. Relationship between the relative Se variation in maternal blood between day 5 and day 22 of lactation (Se $\Delta_{\text {rel }}$ ) and the relative THg variation in maternal blood during lactation (THg $\Delta_{\text {rel }}$ ) (Bravais-Pearson correlation; $r=0.80, P=0.005, n=10$ ).

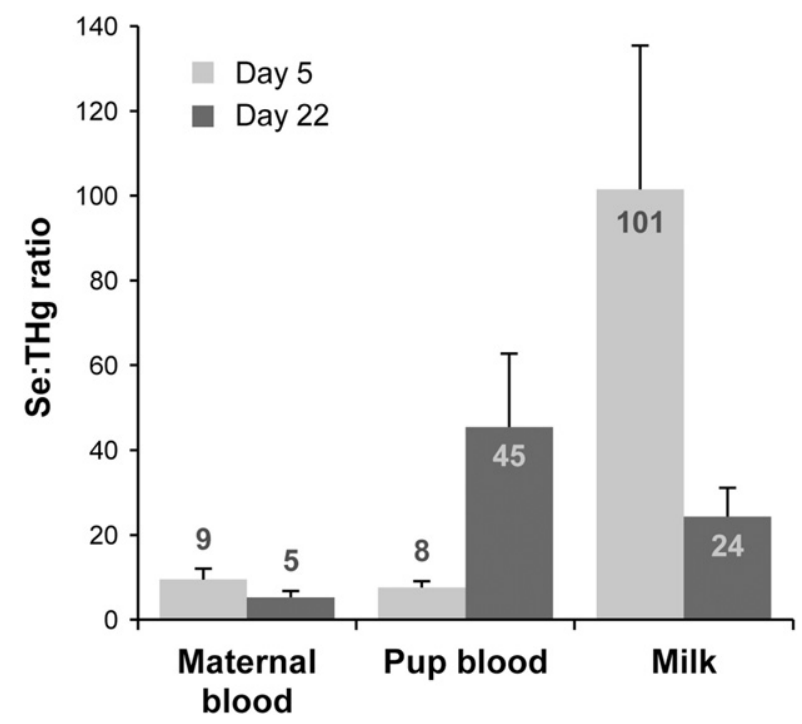

Fig. 3. Se:THg molar ratios in blood and milk. Molar ratios of Se and THg (mean \pm SD) in the blood and milk of northern elephant seal mothers and pups on days 5 (light bars) and 22 (dark bars) of lactation.

on days 5 and 22, respectively). Milk appears well regulated and the mammary glands would exert an important role in restricting the transfer of $\mathrm{Hg}$ to milk (Dorea, 2004). Levels of THg measured in harp seal milk (averaging $6.5 \mathrm{ng} / \mathrm{g}$ ww, Wagemann et al., 1988) were lower than in NES milk. Much higher THg levels have been found in some odontocete milk (Table 4), but these values were measured in single stranded or accidentally caught individuals.

Neonate pups had high blood THg levels relative to their mothers and levels declined with the progression of lactation. This suggests that a high $\mathrm{Hg}$ transfer through the placenta occurred. As reported in previous studies (Brookens et al., 2007; Dorea, 2004), the placenta plays a greater role in $\mathrm{Hg}$ transfer to offspring than does milk. This high $\mathrm{Hg}$ transfer during gestation raises the question of how $\mathrm{Hg}$ exposure affects the offspring during its most sensitive period of development. The main form of $\mathrm{Hg}$ transferred through the placenta, MeHg (Ask et al., 2002; Wagemann et al., 1988), can affect the normal neuronal development and the immune system of offspring (National

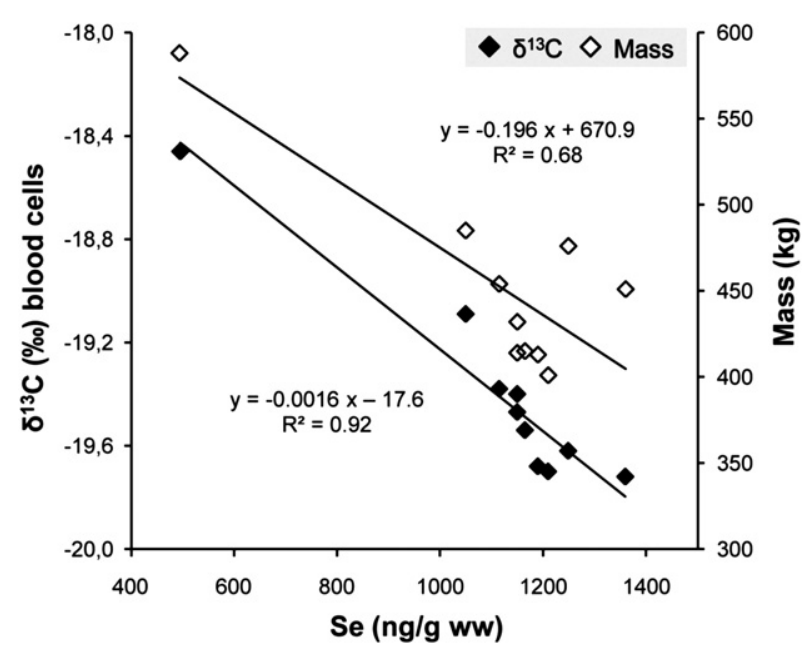

Fig. 4. Relationship between maternal Se levels, dietary indicators $\left(\delta^{13} \mathrm{C}\right)$ and body mass. Relationship between Se levels in maternal blood and $\delta^{13} \mathrm{C}$ values in maternal blood cells (black diamond), and Se levels and maternal body mass (open diamond) on day 5 of lactation (Bravais-Pearson correlation; $P<0.005, n=10$ ). 
Table 4

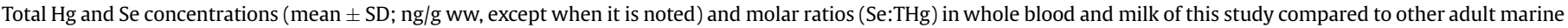
mammals.

\begin{tabular}{|c|c|c|c|c|c|c|c|}
\hline & Comment & $n$ & $\mathrm{THg}$ & $\mathrm{Se}$ & & Se:THg & Source \\
\hline \multicolumn{8}{|l|}{ Whole blood } \\
\hline Northern elephant seal & , early lactation & 10 & $308 \pm 68$ & $1113 \pm 232$ & & 9 & This study \\
\hline Northern elephant seal & ㅇ, late lactation & 10 & $593 \pm 130$ & $1179 \pm 220$ & & 5 & This study \\
\hline Southern elephant seal & ๙, Antarctica & 6 & $100 \pm 15$ & & & & Baraj et al. (2001) \\
\hline Harbor seal & California & 106 & $302 \pm 23$ & & & & Brookens et al. (2007) \\
\hline Harbor seal & Europe & 22 & $160 \pm 130$ & & & & Das et al. (2008) \\
\hline Harbor seal & Europe & 85 & & $885^{\mathrm{a}}$ & $\mu \mathrm{g} / \mathrm{l}$ & & Griesel et al. (2008) \\
\hline Pilot whale & 우 & 6 & $253 \pm 99$ & $993 \pm 255$ & $\mu \mathrm{g} / \mathrm{l}$ & 10 & Nielsen et al. (2000) \\
\hline Sperm whale & $\sigma^{*}$ & 4 & $1042 \pm 960$ & $569 \pm 174$ & $\mu \mathrm{g} / \mathrm{l}$ & 2 & Nielsen et al. (2000) \\
\hline Bottlenose dolphin & $0^{\star}$, Florida & 23 & $691 \pm 388$ & $781 \pm 147$ & & 3 & Bryan et al. (2007) \\
\hline Bottlenose dolphin & ๑๐, Florida & 47 & $626 \pm 404$ & $603 \pm 104$ & $\mu \mathrm{g} / \mathrm{l}$ & 2 & Stavros et al. (2008a) \\
\hline Bottlenose dolphin & ণক', South Carolina & 51 & $165 \pm 97$ & $759 \pm 157$ & $\mu \mathrm{g} / \mathrm{l}$ & 12 & Stavros et al. (2008a) \\
\hline Bottlenose dolphin & Adults and juveniles & $55 / 46^{\mathrm{b}}$ & $570 \pm 434$ & $760 \pm 180$ & & & Woshner et al. (2008) \\
\hline Florida manatees & Adults and juveniles & $7 / 8^{\mathrm{b}}$ & $8 \pm 17$ & $245 \pm 91$ & & & Stavros et al. (2008b) \\
\hline \multicolumn{8}{|l|}{ Milk } \\
\hline Northern elephant seal & Early lactation & 10 & $24 \pm 6$ & $920 \pm 244$ & & 101 & This study \\
\hline Northern elephant seal & Late lactation & 10 & $35 \pm 12$ & $314 \pm 77$ & & 24 & This study \\
\hline Harp seal & & $5 / 8^{\mathrm{b}}$ & $6 \pm 3$ & $140 \pm 100$ & & 50 & Wagemann et al. (1988) \\
\hline Bottlenose dolphin & & 1 & 2000 & & dw & & Frodello et al. (2002) \\
\hline Amazon river dolphin & & 1 & 176 & & $\mu \mathrm{g} / \mathrm{l}$ & & Rosas and Lehti (1996) \\
\hline Franciscana dolphin & & 1 & 0.2 & & $\mu \mathrm{g} / \mathrm{l}$ & & Caon et al. (2008) \\
\hline Stejneger's beaked whale & & & & 360 & & & Ullrey et al. (1984) \\
\hline California sea lion & & & & 450 & & & Oftedal et al. (1987) \\
\hline
\end{tabular}

a Median.

b $n=x / y$ for $\mathrm{Hg}$ and Se analysis, respectively.

Research Council, 2000), potentially having consequences to future growth and fitness.

Blood THg levels in mothers and pups varied significantly during lactation. While maternal levels increased, pup levels were reduced by half between the beginning and the end of lactation. The pup mass quickly increases throughout the suckling period and becomes about 3-4 times that at birth. Consequently, the rapid increase in body volume, a progressive accumulation in expanding pup tissue compartments, and the limited $\mathrm{Hg}$ uptake from milk, likely caused the dilution in blood $\mathrm{THg}$ levels during lactation. Several studies have reported $\mathrm{Hg}$ in the lanugo (natal hair) of pinnipeds (from 1.25 to 14 ppm, Beckmen et al., 2002; Hyvärinen et al., 1998). These relatively high THg values indicate the fetus is already able to 'excrete' $\mathrm{Hg}$ in utero effectively, concentrating $\mathrm{Hg}$ in the prenatal hair growth. NES pups molt early in the post-weaning fast. Consequently, production of the new pelage, probably beginning in the end of lactation, might contribute to the decreasing $\mathrm{THg}$ levels via $\mathrm{Hg}$ excretion in new hair.

Although gestation and lactation may allow $\mathrm{Hg}$ excretion for mothers, blood values showed increasing THg levels during lactation. Northern elephant seals, like several other true seal species, fast during lactation. Lactating and fasting females must thus meet both their own metabolic requirements and the nutrient requirements for milk production. Mobilization of energy reserves increases with the progression of lactation (Houser et al., 2007), potentially increasing the release of $\mathrm{Hg}$ into the blood of the mothers. Moreover, the mothers underwent a substantial decrease of their blood volume linked to the mass lost over lactation (Hassrick et al., 2010), also concentrating $\mathrm{Hg}$ into the blood.

The main part of $\mathrm{Hg}$ is bound to hemoglobin in the red blood cells (RBCs) (Ancora et al., 2002; Berglund et al., 2005). Therefore, changes in hemoglobin concentration (or in hematocrit) can affect $\mathrm{Hg}$ levels measured in whole blood. In phocids, these hematological parameters, related to the oxygen storage and transport capacity, increase throughout the postnatal development to assure diving capabilities from pups to juveniles (Lewis et al., 2001; Noren et al., 2005; Thorson and Le Boeuf, 1994). NES have longer postpartum terrestrial periods than other phocids, and the increase in blood parameters seems to occur after weaning (Lewis et al., 2001; Thorson and Le Boeuf, 1994). No significant hemoglobin variation was observed between early and late lactation in mothers and pups, and between mother and pup at birth (Lewis et al., 2001). Nevertheless, it would be interesting to include this parameter for the next studies when using whole blood in $\mathrm{Hg}$ measurements.

Selenium was found in substantial quantities in NES milk, especially in early lactation. The mammary-gland regulating mechanism controls the synthesis and secretion of Se compounds throughout lactation, with the highest amount of Se excreted in the beginning of lactation (Dumont et al., 2006). In human milk, worldwide Se values range between 13 and $33 \mu \mathrm{g} / \mathrm{l}$ and variations in levels are mainly due to fluctuations in the Se intake via food (Dumont et al., 2006). A decline of the Se secretion into the human milk also occurs during lactation, especially after the protein-rich colostrum is delivered (Dorea, 2002). Information on Se in marine mammals is limited, but the same dynamics of Se during lactation was shown in pigs (Kim and Mahan, 2001). Similar levels in blood and milk were observed from birth to weaning in sows and their offspring when organic or inorganic Se source was fed to the sows. At these blood levels, toxic effects were shown: organic Se seemed to express the selenotic effects more on reproductive performance during gestation, whereas inorganic Se was more detrimental to the nursing pig during lactation (Kim and Mahan, 2001). Although marine mammals appear to be less sensitive to dietary organic Se exposure, little information exists about the Se toxicity in these animals (Janz et al., 2010). Results in pigs suggest that potential toxic effects on gestation and lactation in NES cannot be excluded.

Unlike $\mathrm{Hg}$, the Se uptake from the milk appears higher than from the placenta in NES. Indeed, effects of suckling caused a high increase of Se levels in pup blood despite the decreasing Se levels in milk and the potential dilution effect, which is associated to the rapid weight gain of the pup. Other studies also reported a transfer limited through the placenta for this essential element: Se concentration in offspring serum was $55 \%$ of the maternal value in humans (Rossipal et al., 2000) and about 45\% in pigs (Kim and Mahan, 2001). 
No relationship was found between THg and Se in blood or milk. This indicates that the process of $\mathrm{Hg}$ transfer through the placenta or through the milk is not the same and does not display similar kinetics to that of the Se transfer. Only a concomitant increase of THg and Se levels in maternal blood was observed between early and late lactation. The varying molar ratios of Se:THg in blood and milk also revealed the absence of a strong relationship between the two elements. Likewise, Woshner et al. (2008) observed a weak relationship between $\mathrm{Hg}$ and $\mathrm{Se}$ in the blood of bottlenose dolphins. A strong correlation and equimolar ratio were found especially in the livers of marine mammals when the main form of $\mathrm{Hg}$ is inorganic (Cuvin-Aralar and Furness, 1991; Koeman et al., 1973).

Surprisingly, THg levels were not correlated to dietary indicators $\left(\delta^{13} \mathrm{C}, \delta^{15} \mathrm{~N}, \mathrm{C}: \mathrm{N}\right)$ or to any biometric parameter (mass, length, etc.). Only Se levels in maternal blood showed a strong relationship with the $\delta^{13} \mathrm{C}$ values in blood cells (Fig. 4), suggesting that adult females feeding on different $C$ sources undergo a different Se exposure. NES females feed mainly on epi- and mesopelagic, bioluminescent cephalopods, and Pacific Hake in the open ocean (Le Boeuf et al., 2000). The lightest and likely youngest females fed on C sources at lower $\delta^{13} \mathrm{C}$ values and showed higher Se levels in their blood. Marine mammals seem to accumulate high quantities of Se from their dietary intake. By comparing to the available literature (Table 4), it appears that NES have the highest Se concentrations in their blood, followed by pilot whales (Globicephala melas). Both species are known to eat mainly cephalopods, which might contain high Se levels. Blood Hg concentrations in NES were in the same range of values than other species. However, these comparisons give only a rough idea of $\mathrm{Hg}$ accumulation processes in the NES. Indeed, the influence of gestation on $\mathrm{Hg}$ and Se levels in adult NES females is still unknown, and physiological status of animals in other studies was seldom available or mentioned.

\section{Conclusions}

A transmammary transfer of mercury and selenium was shown in the northern elephant seal. This study also suggests that the maternal transfer of Se is prominent during lactation, whereas the $\mathrm{Hg}$ transfer is larger during gestation. Lactation and fasting affect THg and Se levels in the blood and milk of mother seals. Milk consumption and tissue deposition (i.e., growth and development) impact the contaminant dynamics in the pups. Such processes must be considered carefully when interpreting trace element levels in the framework of biomonitoring. According to our knowledge, $\mathrm{Hg}$ and Se levels have not been previously determined in this species. Further toxicological studies are needed to understand the impact of these elemental transfers on NES health.

\section{Acknowledgments}

This study was performed at the Año Nuevo State Reserve, a part of the University of California Natural Reserve System. The authors are grateful to R. Biondo for his technical assistance. The authors would also like to thank $C$. Champagne and M. Fowler for their assistance with sample collection and the park rangers of Año Nuevo for their cooperation in this study. We would additionally like to acknowledge the Clairol Corporation for providing hair dye as use as a marking solution. K.D. is a F.R.S.-FNRS Research Associate. S.H. is a F.R.S.-FNRS Research fellow. This study was supported by NSF grant \#0213095 and by FRFC grant \#2.4502.07 (F.R.S.-FNRS). Research was conducted under National Marine Fisheries Service marine mammal research permit \#786-1463 and all animalhandling procedures were approved by the Institutional Animal Care and Utilization Committee of the University of California, Santa Cruz. This paper is a MARE publication 211.

\section{References}

Ancora, S., Rossi, R., Di Simplicio, P., Lusini, L., Leonzio, C., 2002. In vitro study of methylmercury in blood of bottlenose dolphin (Tursiops truncatus). Archives of Environmental Contamination and Toxicology 42, 348-353.

Andrade, S., Carlini, A.R., Vodopivez, C., Poljak, S., 2007. Heavy metals in molted fur of the southern elephant seal Mirounga leonina. Marine Pollution Bulletin 54, 602-605.

Ask, K., Akesson, A., Berglund, M., Vahter, M., 2002. Inorganic mercury and methylmercury in placentas of Swedish women. Environmental Health Perspectives 110, 523-526.

Baraj, B., Bianchini, A., Niencheski, L.F.H., Campos, C.C.R., Martinez, P.E., Robaldo, R.B. Muelbert, M.M.C., Colares, E.P., Zarzur, S., 2001. The performance of Zeiss GFAAS-5 instrument on the determination of trace metals in whole blood samples of southern elephant seals (Mirounga leonina) from Antarctica. Fresenius Environmental Bulletin 10, 859-862.

Beckmen, K.B., Duffy, L.K., Zhang, X., Pitcher, K.W., 2002. Mercury concentrations in the fur of Steller sea lions and northern fur seals from Alaska. Marine Pollution Bulletin 44, 1130-1135.

Berglund, M., Lind, B., Björnberg, K.A., Palm, B., Einarsson, Ö, Vahter, M., 2005. Interindividual variations of human mercury exposure biomarkers: a cross-sectional assessment. Environmental Health 4, 20.

Bossart, G.D., 2006. Marine mammals as sentinel species for oceans and human health. Oceanography 19, 134-137.

Brookens, T.J., Harvey, J.T., O'Hara, T.M., 2007. Trace element concentrations in the Pacific harbor seal (Phoca vitulina richardii) in central and northern California. Science of the Total Environment 372, 676-692.

Bryan, C.E., Christopher, S.J., Balmer, B.C., Wells, R.S., 2007. Establishing baseline levels of trace elements in blood and skin of bottlenose dolphins in Sarasota Bay, Florida: implications for non-invasive monitoring. Science of the Total Environment 388, 325-342.

Caon, G., Secchi, E.R., Capp, E., Kucharski, L.C., 2008. Milk composition of franciscana dolphin (Pontoporia blainvillei) from Rio Grande do Sul, Southern Brazil. Journal of the Marine Biological Association of the United Kingdom 88, 1099-1101.

Caurant, F., Amiard, J.C., Amiard-Triquet, C., Sauriau, P.G., 1994. Ecological and biological factors controlling the concentrations of trace elements (As, $\mathrm{Cd}, \mathrm{Cu}, \mathrm{Hg}$ $\mathrm{Se}, \mathrm{Zn}$ ) in delphinids Globicephala melas from the North Atlantic Ocean. Marine Ecology Progress Series 103, 207-219.

Crocker, D.E., Williams, J.D., Costa, D.P., Le Boeuf, B.J., 2001. Maternal traits and reproductive effort in northern elephant seals. Ecology 82, 3541-3555.

Cuvin-Aralar, M.L., Furness, R.W., 1991. Mercury and selenium interaction: a review. Ecotoxicology and Environmental Safety 21, 348-364.

Das, K., Debacker, V., Pillet, S., Bouquegneau, J.M., 2003. Heavy metals in marine mammals. In: Vos, J.G., Bossart, G.D., Fournier, M., O'Shea, T.J. (Eds.), Toxicology of Marine Mammals. Taylor \& Francis, London, pp. 135-167.

Das, K., Siebert, U., Gillet, A., Dupont, A., Di-Poï, C., Fonfara, S., Mazzucchelli, G., De Pauw, E., De Pauw-Gillet, M.-C., 2008. Mercury immune toxicity in harbour seals: links to in vitro toxicity. Environmental Health 7.

Debier, C. Chalon, C., Le Boeuf, B.J., de Tillesse, T., Larondelle, Y., Thome, J.P., 2006. Mobilization of PCBs from blubber to blood in northern elephant seals (Mirounga angustirostris) during the post-weaning fast. Aquatic Toxicology 80, 149-157.

Debier, C., Pomeroy, P.P., Dupont, C., Joiris, C., Comblin, V., Le Boulenge, E., Larondelle, Y., Thome, J.P., 2003. Quantitative dynamics of PCB transfer from mother to pup during lactation in UK grey seals Halichoerus grypus. Marine Ecology Progress Series 247, 237-248.

Dehn, L.A., Follmann, E.H., Thomas, D.L., Sheffield, G.G., Rosa, C., Duffy, L.K., O'Hara, T.M., 2006. Trophic relationships in an Arctic food web and implications for trace metal transfer. Science of the Total Environment 362, 103-123.

Dorea, J.G., 2002. Selenium and breast-feeding. British Journal of Nutrition 88, $443-461$.

Dorea, J.G., 2004. Mercury and lead during breast-feeding. British Journal of Nutrition 92, 21-40.

Dumont, E., Vanhaecke, F., Cornelis, R., 2006. Selenium speciation from food source to metabolites: a critical review. Analytical and Bioanalytical Chemistry 385 , 1304-1323.

Fossi, M.C., Marsili, L., 1997. The use of non destructive biomarkers in the study of marine mammals. Biomarkers 2, 205-216.

Frodello, J.P., Viale, D., Marchand, B., 2002. Metal concentrations in the milk and tissues of a nursing Tursiops truncatus female. Marine Pollution Bulletin 44, $551-554$.

Gallagher, P.J., Lee, R.L., 1980. The role of biotransformation in organic mercury neurotoxicity. Toxicology 15, 129-134.

Gray, R., Canfield, P., Rogers, T., 2008. Trace element analysis in the serum and hair of Antarctic leopard seal, Hydrurga leptonyx, and Weddell seal, Leptonychotes weddellii. Science of the Total Environment 399, 202-215.

Griesel, S., Kakuschke, A., Siebert, U., Prange, A., 2008. Trace element concentrations in blood of harbor seals (Phoca vitulina) from the Wadden Sea. Science of the Total Environment 392, 313-323.

Habran, S., Debier, C., Crocker, D.E., Houser, D.S., Lepoint, G., Bouquegneau, J.-M., Das, K., 2010. Assessment of gestation, lactation and fasting on stable isotope ratios in northern elephant seals (Mirounga angustirostris). Marine Mammal Science 26, 880-895.

Hassrick, J.L., Crocker, D.E., Teutschel, N.M., McDonald, B.I., Robinson, P.W., Simmons, S.E., Costa, D.P., 2010. Condition and mass impact oxygen stores and 
dive duration in adult female northern elephant seals. Journal of Experimental Biology 213, 585-592.

Houser, D.S., Champagne, C.D., Crocker, D.E., 2007. Lipolysis and glycerol gluconeogenesis in simultaneously fasting and lactating northern elephant seals. American Journal of Physiology - Regulatory Integrative and Comparative Physiology 293, R2376-R2381.

Hyvärinen, H., Sipilä, T., Kunnasranta, M., Koskela, J.T., 1998. Mercury pollution and the Saimaa ringed seal (Phoca hispida saimensis). Marine Pollution Bulletin 36, $76-81$

Ikemoto, T., Kunito, T., Hanaka, H., Baba, N., Miyazaki, N., Tanabe, S., 2004. Detoxification mechanism of heavy metals in marine mammals and seabirds: interaction of selenium with mercury, silver, copper, zinc, and cadmium in liver. Archives of Environmental Contamination and Toxicology 47, 402-413.

Janz, D.M., DeForest, D.K., Brooks, M.L., Chapman, P.M., Gilron, G., Hoff, D., Hopkins, W.A., McIntyre, D.O., Mebane, C.A., Palace, V.P., Skorupa, J.P., Wayland, M., 2010. Selenium toxicity to aquatic organisms. In: Chapman, P.M. Adams, W.J., Delos, C.G., Luoma, S.N., Maher, W.A., Ohlendorf, H.M., Presser, T.S., Shaw, D.P. (Eds.), Ecological Assessment of Selenium in the Aquatic Environment, first ed. CRC Press, Pensacola, FL, pp. 141-232.

Kakuschke, A., Valentine-Thon, E., Griesel, S., Fonfara, S., Siebert, U., Prange, A 2005. Immunological impact of metals in harbor seals (Phoca vitulina) of the North Sea. Environmental Science \& Technology 39, 7568-7575.

Khan, M.A.K., Wang, F., 2009. Mercury-selenium compounds and their toxicological significance: toward a molecular understanding of the mercury-selenium antaganism. Environmental Toxicology and Chemistry 28, 1567-1577.

Kim, Y.Y., Mahan, D.C., 2001. Prolonged feeding of high dietary levels of organic and inorganic selenium to gilts from $25 \mathrm{~kg}$ body weight through one parity. Journal of Animal Science and Technology 79, 956-966.

Koeman, J.H., Peeters, W.H.M., Koudstaal-Hol, C.H.M., Tjioe, P.S., De Goeij, J.J.M., 1973. Mercury-selenium correlations in marine mammals. Nature 245 , 385-386.

Lahaye, V., Bustamante, P., Dabin, W., Churlaud, C., Caurant, F., 2007. Trace element levels in foetus-mother pairs of short-beaked common dolphins (Delphinus delphis) stranded along the French coasts. Environment International 33, 1021-1028.

Le Boeuf, B.J., Crocker, D.E., Costa, D.P., Blackwell, S.B., Webb, P.M., Houser, D.S. 2000. Foraging ecology of northern elephant seals. Ecological Monographs 70, 353-382.

Le Boeuf, B.J., Laws, R.M., 1994. Elephant seals: an introduction to the genus. In: Le Boeuf, B.J., Laws, R.M. (Eds.), Elephant Seals: Population Ecology, Behavior, and Physiology. University of California Press, Berkeley, CA, USA, pp. 1-26.

Lewis, M., Campagna, C., Uhart, M., Ortiz, C.L., 2001. Ontogenetic and seasonal variation in blood parameters in southern elephant seals. Marine Mammal Science 17, 862-872.

Martoja, R., Berry, J.P., 1980. Identification of tiemannite as a probable product of demethylation of mercury by selenium in cetaceans: a complement to the scheme of the biological cycle of mercury. Vie et Milieu 30, 7-10.

Monaci, F., Borrel, A., Leonzio, C., Marsili, L., Calzada, N., 1998. Trace elements in striped dolphins (Stenella coeruleoalba) from the western Mediterranean. Environmental Pollution 99, 61-68.

National Research Council, 2000. Toxicological Effects of Methylmercury. National Academy Press, Washington, DC.

Nielsen, J.B., Nielsen, F., Jørgensen, P.-J., Grandjean, P., 2000. Toxic metals and selenium in blood from pilot whales (Globicephala melas) and sperm whales (Physeter catodon). Marine Pollution Bulletin 40, 348-351.
Nigro, M., Leonzio, C., 1996. Intracellular storage of mercury and selenium in different marine vertebrates. Marine Ecology Progress Series 135, 137-143.

Noren, S.R., Iverson, S.J., Boness, D.J., 2005. Development of the blood and muscle oxygen stores in gray seals (Halichoerus grypus): implications for juvenile diving capacity and the necessity of a terrestrial postweaning fast. Physiological and Biochemical Zoology 78, 482-490.

Oftedal, O.T., Boness, D.J., Tedman, R.A., 1987. The behavior, physiology and anatomy of lactation in the pinnipedia. In: Genoways, H.H. (Ed.), Current Mammalogy, first ed. Springer, New York, pp. 175-245.

Riedman, M., Ortiz, C.L., 1979. Changes in milk composition during lactation in the northern elephant seal. Physiological Zoology 52, 240-249.

Rosas, F.C.W., Lehti, K.K., 1996. Nutritional and mercury content of milk of the Amazon River Dolpin, Inia geoffrensis. Comparative Biochemistry and Physiology Part A 115A, 117-119.

Rossipal, E., Krachler, M., Li, F., Micetic-Turk, D., 2000. Investigation of the transport of trace elements across barriers in humans: studies of placental and mammary transfer. Acta Paediatrica 89, 1190-1195.

Stavros, H.-C.W., Bonde, R.K., Fair, P.A., 2008b. Concentrations of trace elements in blood and skin of Florida manatees (Trichechus manatus latirostris). Marine Pollution Bulletin 56, 1221-1225.

Stavros, H.-C.W., Bossart, G.D., Hulsey, T.C., Fair, P.A., 2008a. Trace element concentrations in blood of free-ranging bottlenose dolphins (Tursiops truncatus): influence of age, sex and location. Marine Pollution Bulletin 56, 348-379.

Storelli, M.M., Marcotrigiano, G.O., 2000. Environmental contamination in bottlenose dolphin (Tursiops truncatus): relationship between levels of metals, methylmercury, and organochlorine compounds in an adult female, her neonate, and a calf. Bulletin of Environmental Contamination and Toxicology $64,333-340$.

Sunderland, E.M., Krabbenhoft, D.P., Moreau, J.W., Strode, S.A., Landing, W.M., 2009. Mercury sources, distribution, and bioavailability in the North Pacific Ocean: insights from data and models. Global Biogeochemical Cycles 23, 14.

Thorson, P.H., Le Boeuf, B.J., 1994. Developmental aspects of diving in northern elephant seal pups. In: Le Boeuf, B.J., Laws, R.M. (Eds.), Elephant Seals: Population Ecology, Behavior, and Physiology. University of California Press, Berkeley, CA, USA, pp. 271-289.

Ullrey, D.E., Schwartz, C.C., Whetter, P.A., Rajeshwar Rao, T., Euber, J.R., Cheng, S.G. Brunner, J.R., 1984. Blue-green color and composition of Stejneger's beaked whale (Mesoplodon stejnegeri) milk. Comparative Biochemistry and Physiology Part B: Comparative Biochemistry 79, 349-352.

Wagemann, R, Stewart, R.E.A, Lockhart, W.L, Stewart, B.E, Povoledo, M, 1988 Trace metals and methyl mercury: associations and transfer in harp seal (Phoca groenlandica) mothers and their pups. Marine Mammal Science 4, 339-355.

Woshner, V., Knott, K., Wells, R, Willetto, C. Swor, R, O'Hara, T, 2008. Mercury and selenium in blood and epidermis of bottlenose dolphins (Tursiops truncatus) from Sarasota Bay, FL: interaction and relevance to life history and hematologic parameters. EcoHealth 5, 360-370.

Yang, J., Kunito, T., Anan, Y., Tanabe, S., Miyazaki, N., 2004. Total and subcellular distribution of trace elements in the liver of a mother-fetus pair of Dall's porpoises (Phocoenoides dalli). Marine Pollution Bulletin 48, 1122-1129.

Yang, J., Kunito, T., Anan, Y., Tanabe, S., Miyazaki, N., 2008. Subcellular distribution of trace elements in kidney of a mother-fetus pair of Dall's porpoises (Phocoenoides dalli). Chemosphere 70, 1203-1210.

Yoneda, S., Suzuki, K.T., 1997. Equimolar Hg-Se complex binds to selenoprotein P. Biochemical and Biophysical Research Communications 231, 7-11. 